験者データを用いた結果では, カットオフ周波数が低いデータベー スの場合は脳表抽出分布がはけて見にくく，Z-score mapは広がりを 見せた，またZ-score mapと乘離するものもあった. iSSP付属ノーマ ルデータベースとの比較では，基準とする場所でZ值が異なってい た。

【考察】データベース構築の際にカットオフ周波数を下げすぎると， 微少な血流・代謝低下部位を見落としやすく, 解剖学的部位の同定 が困難になると思われる。

161 脳血流SPECTのコリメータおよび画像処理方法の違いが 3D-SSP解析結果に及ほす影響

千葉大学医学部附属病院·放射線部 木川隆司，飯森隆志，高橋三幸 深谷美絵，守田文範

【目的】3D-SSP(three-dimensional stereotactic surface projections)は統計学 的手法を用いて, 脳SPECT ・ PET検査より脳血流代謝低下部位を客観 的に描出する解析方法である。多施設共有のノーマルデータベース構 築を視野に入れて，脳血流SPECT時におけるコリメータおよび画像処 理方法の違いが3D-SSP解析結果に及ほす影響について検討した.

【使用装犆】ガンマ-カメラおよびデー夕処理装置 PICKER社 PRISM3000XP, Odyssey-VP, コリメータ LEUHR-FAN, LEHRPAR, MEGAP-PAR, ファントム（J-ジャック）IB-10 型, HOFFMANブレインファントム

【方法】1)空間分解能の評価： ${ }^{99} \mathrm{~m} \mathrm{Tc}$ または123Iを注入した脳ファント ムを用いて，PICKER社製PRISM3000XPでそれぞれのコリメータの 空間分解能評価を行った. 2) 臨床評価：Alzheimer型痴呆(DAT)症例 に対してコリメー夕を変え脳血流SPECTを行い，画像構築時にChan の吸収補正を用いてその吸収補正係数を変化させ3D-SSP解析結果の Z-SCORE mapに及ぼす影響について比較・検討した。

【結果】3D-SSP解析結果においてコリメー夕の種類あるいは吸収補正 係数によりZ-SCORE值に違いが認められたがZ-SCORE mapのパター ンに大きな違いはみられなかった。

【結語】コリメータの種類，あるいは画像処理方法により3D-SSP解析結 果に大きな影響は認められなかった．しかし今後，多施設間でのノー マルデータベースの共有化を考慮すると, さらに検討が必要である.

162 媨血流SPECTにおける装固の違いが3D-SSP解析結果に及ほ す影響について

千葉大学医学部附属病院·放射線部飯森隆志，木川隆司，高橋三幸 深谷美絵，守田文範

【目的】ミシガン大学のMinoshimaらによって開発された3D-SSP (three-dimensional stereotactic surface projections)は脳のSPECT · PET において統計学的手法を用いて，脳血流代謝低下部位を客観的に描 出する解析方法である. 今回, 脳血流SPECT時における装置 (3 検出 器および 2 検出器)の違いが3D-SSP解析結果に及ほす影響について 検討した。

【使用装置】PICKER社製：PRISM3000XP，2000XP Odyssey-VP，京都 科学社製：脳ファントム (J-ジャック) IB-10型

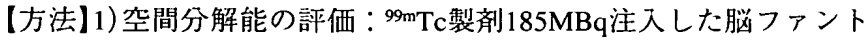
ム(J-ジャック)を用いて，PICKER社製PRISM3000XP，2000XPそれ ぞれの空間分解能の評価を行った．2)臨床評価：Alzheimer型痴呆 (DAT) 症例 5 例に対して, 上記の 2 機種に扔ける脳血流SPECTを 行った.さらにこれらの画像について3D-SSP解析を行い，Z-SCORE mapに及ほす影隌について比較，検討した。

【結果】空間分解能における評価はPRISM3000がPRISM2000に比べ良 好な結果が得られた。 また臨床では装置の違いにより3D-SSP解析結 果 (Z-SCORE map)に及ほすす影響は視覚的に認められなかった.

【結語】今回，装置の違いによる3D-SSP解析結果に影響は認められな かった. しかし今後, 多施設間でのノーマルデータベースの共有化
を考慮すると，さらにハード，およびソフト面での比較・検討が必 要であると思われる。

163 異機種間の3D-SSP Z-Score Mapの違い 島根医科大学医学部附属病院・放射線部 山本泰司，原元益夫 小松明夫

島根医科大学・放射線医学講座 内田幸司

【目的】われわれは58回日本放射線技術学会総会においてPRISM IRIX (PICKER) で構築した3D-SSP用データベースの処理条件について検 討した. 今回，E-CAM(SIEMENS)で同様な検討を加えZ-Score Map およびZ-Score Valueが装置間でどのような差を生じるか検討した。

【方法】3D-Brain Fhantomでそれぞれの装置でのデータベースを作成 し，同じファントムに低濃度信号を埋め込みデータ収集を行った。 それらのデータを3D-SSP解析を行いZ-Score Map, Z-Score Valueの 差異について検討した。

【結果】参照部位によっては，おのおののデータベース間で標準偏差 と平均値に差を生じ，その結果Z-Score MapおよびZ-Score Valueに変 化を生じた。

【考察】同じファントムでありながら，平均值と標準偏差に差を生じ るのは装置間の性能と，画像処理条件によると思われる。

\section{4 脳血流の統計学的解析方法NSNとeZISの比較検討}

日本大学医学部附属板橋病院 -中央放射線部 小沼 弘, 佐藤幸光 阿部勝彦，伊藤英夫，鹿沼成美

駿河台日本大学病院 放射線部 奥野光男

日本大学医学部・放射線科 奥畑好孝

【目的】脳血流の評価法として, 統計学的手法を用いたNSN (Neurostat Navigator) とeZIS (easy z-score imaging system)がある. 同一のデータ を使用しNSNとeZISで脳血流低下領域を算出しそれらの検出領域数 について検討した。

【方法】当院で脳血流SPECTを施行した60歳から69歳の者でSPM研究 会の基準を満たす 7 例をノーマルファイルとした．そのノーマル ファイルと60歳代の患者データ 9 症例をNSNとeZISを用いて解析を 行った。結果をR-Lateral, L-Lateralの前頭葉，頭頂葉，側頭葉，後 頭葉とに分け，2Z抢よび3Z以上を血流低下とした場合でのNSNと eZISの検出領域数に差があるか検討した.

【結果】2Z以上で数えた場合のNSNは, 前頭葉19, 頭頂葉 15 , 側頭葉 11 , 後頭葉 4 の合計49領域. eZISは, 前頭葉 16 , 頭頂葉 14 , 側頭葉 9, 後頭葉 3 の合計42領域であった。 3Z以上で数えた場合のNSNは, 前頭葉 12 , 頭頂葉 9, 側頭葉 3, 後頭葉 3 の合計27領域. eZISは, 前頭葉 10 , 頭頂葉 11 , 側頭葉 1 , 後頭葉 0 の合計22領域であった. 【考察】脳血流低下領域の検出数は, eZISに比べてNSNの方が多かっ た. eZISが少なかった理由は，その算出過程においてスムージング を行うために，小さな領域が平均化され，ピークカウントが低下す ることによるものと考えられた.

\section{5 媨SPECTにおける収集条件の画質への影響}

南松山病院·放射線科 中村夢美, 平岡茂行, 高橋 保, 大野裕美子 宮内嘉玄

愛媛大学医学部附属病院・放射線部 中田 茂

【目的】SPECT画像の画質を良くするためには，ピクセルサイズを小 さくして十分なカウント数を得ることと，ステップ角度を小さくし てアーチファクトを滅少させることであると報告されている．今 回, 脳SPECTにおける検査時間の短縮を目的に, ピクセルサイズ. ステップ角度・カウント数の画質への影響について検討した.

【方法】脳ファントムを用いて収集条件を変えてSPECT画像を作成 し，画質を視覚的に 5 段階評価で判定した．収集条件は，ピクセル サイズを1.88，3.77mm，ステップ角度を $3 ， 5 ， 10 ， 20$ degrees，検査 